\title{
Polycyclic Aromatic Hydrocarbons: Role of Apoptosis in Dermatotoxic and Carcinogenic Effects in Some Asphalt Road Paving Egyptian Workers
}

\author{
Ghada Attia Eshak, Morid Malak Hanna', Manal Ismael Ahmed², and Ghada \\ Ali Nassef3
}

\footnotetext{
${ }^{1}$ Forensic Medicine \& Clinical Toxicology Department

${ }^{2}$ Pathology Department

${ }^{3}$ Dermatology, STDs, and Andrology Department
}

Faculty of Medicine, Minia University, Minia, Egypt

All rights reserved.

\begin{abstract}
This study aimed firstly to assess the dermatotoxic and carcinogenic risk associated with chronic asphalt fumes exposure, and secondly to investigate the cancer causal relationship by examining the expression pattern of P53, Bax and Bcl-2 apoptotic proteins in skin specimens from road paving workers. The study was conducted on one hundred and fifty two male subjects classified into 122 asphalt fumes exposed workers and 30 non exposed workers; skin examination and skin biopsies were obtained from all participants after written consent. Biopsies were examined histopathologically and immunohistochemically. Results showed that $58.19 \%$ of exposed workers had erythema, itching, excoriations, chronic dermatitis, chemical keratosis, keratoacanthoma (K.A) and $7.38 \%$ of exposed workers had squamous cell carcinoma (SCC). Imunohistochemically, wild type P53 was significantly higher in all asphalt exposed workers and mutant type P53 was significantly higher in SCC lesions when compared with control. A significant increase in Bax expression was observed in all exposed workers. A significant decrease in Bcl-2 expression was noted in all workers while none of SCC cases were positive for Bcl-2. It could be concluded that chronic exposure to asphalt fumes may increase the risk for developing dermatotoxic and/or cancer through disturbing P53, Bax and Bcl-2 apoptotic proteins.
\end{abstract}

Keywords Polycyclic aromatic hydrocarbons (PAHs), dermatotoxicity, apoptosis, skin cancer, asphalt workers

\section{Introduction}

A sphalts are complex hydrocarbon mixtures with molecular weights ranging from 500 to 2000 , high boiling temperature (above $500^{\circ} \mathrm{C}$ ) and carbon numbers predominantly higher than $\mathrm{C} 25$. Asphalts produced from the atmospheric and vacuum distillation of crude oil are used primarily in paving applications (Ceinwen, 2011). Asphalt typically contains about $80 \%$ by weight of carbon; around $10 \%$ hydrogen; up to $6 \%$ sulfur; small amounts of oxygen and nitrogen; and trace amounts of metals such as iron, nickel, and vanadium (Michael, 1999).

Asphalt fumes produced during heating of asphalts to facilitate their use commonly are encountered by workers in road paving operations. They are complex mixtures of aerosols and vapors that contain various organic compounds including polycyclic aromatic hydrocarbons (King et al., 1984).

Polycyclic aromatic hydrocarbons "PAHs" are vapors resulting from incomplete combustion or pyrolysis of coal tar, pitch, coke and asphalt. They precipitate as particles or condense onto soot (Harrison, 2004). These fumes may be inhaled or deposited on skin or clothing (Ceinwen, 2011).

The adverse effects of PAHs on humans are diverse (Yvonne, 2007). PAHs have been reported to cause many skin disorders (Bull, 2008); they were reported to be phototoxic (Wang et al., 2007) and verrucae inducer (ATSDR, 1995). Numerous studies have described an excess risk of cancer among asphaltexposed workers (Boffetta et al., 1997; Sivak et al., 1997; Boffetta et al., 2003; Okona-Mensah et al., 2005). PAHs have been shown to be mutagenic in rat lung (Zhaoa et al., 2004), reproductive and developmental toxicant (Parker et al., 2011) as well as genotoxic in humans (Monika et al., 2011).

Apoptosis is a natural, genetically controlled series of steps that occurs when a cell is old, unhealthy, or severely damaged. The end result is cell destruction. 
Apoptosis in the skin kills off harmed cells that they do not turn cancerous. In some cases, genetic mutations or other factors derail apoptosis. If this occurs; the cells can become "immortal" and continue to proliferate, resulting in skin cancer (Timothy, 2009).

The process of apoptosis is controlled by important genes as P53 gene (tumour suppressor gene) and proteins such as Bcl-2 family i.e. several proapoptotic (Bax, Bak, Bad) and anti-apoptotic (Bcl-2, Bcl-xl) proteins and Caspases (Erb et al., 2005).

PAHs compounds have been shown to induce apoptosis in hepatoma cells (Lei et al., 1998), in human B cells (Salas and Burchiel, 1998), in macrophages (Chin et al., 1998) and in rat lungs (Gosset et al., 2003). Though numerous studies have described an excess cancer risk among asphalt workers, a causal relationship has not been established. Accordingly, the aim of this work firstly was to search for the dermatotoxic and carcinogenic risk associated with chronic PAHs exposure in asphalt workers and secondly to evaluate this cancer causal relationship through studying the PAHs effect on apoptosis by examining the expression of P53, Bax and Bcl-2 apoptotic proteins in skin specimens from road paving workers using immunohistochemical techniques.

\section{Subjects and methods}

The study was conducted on 152 male subjects from Minia Governorate classified into two groups: 122 road paving workers who were exposed nearly daily to asphalt fumes " exposed workers" and 30 age-matched non-paving outdoor construction workers with no history of occupational asphalt fumes exposure "control group".

Written informed consent was obtained from each participant after discussing the purpose and the protocol of the study. All procedures were conducted in accordance with a standardized human subject's protocol that was approved by the ethics committee of Faculty of medicine, Minia University.

Over 10-month period, for all subjects, a detailed history of medical status, occupational, and drug administration was taken. Smokers were excluded. Full general, local examination and photographing for any observed skin lesions were undertaken.

\section{Histopathology and immunohistochemistry study}

Four mm punch biopsies were taken from squamous cell carcinoma (SCC) lesions "if found" and from normal uninvolved forearm skin if no lesion were detected (non-lesional skin). Patients with evident skin lesions were then referred to be properly managed. Biopsies were taken according to Alguire and Mathes (1998) who said that the skin biopsy is relative simple, but essential procedure in the diagnosis and management of skin disorders. Properly performed, it may confirm a diagnosis, remove cosmetically unacceptable lesions, and provide definitive treatment for a number of skin conditions. Skin biopsies are unique because the lesion can be visualized, allowing for proper selection biopsy site and technique skin biopsy can be performed with minimal risk even in critically ill patients, and may a timely skin biopsy may avoid other more invasive procedures.

Biopsy specimens underwent routine haematoxylin and eosin light microscopic histopathological examination then evaluated immunohistochemically.

Immunohistochemistry was performed on paraffin wax embedded skin tissue according to Petrusz and Ordronneau (1983). Four $\mu \mathrm{m}$ tissue sections were immunostained for P53, Bax and Bcl-2 proteins using a standard avidin-biotin-peroxidase method. Sections were dewaxed in two changes of xylene, hydrated in graded alcohol. Endogenous peroxidase was blocked with $0.3 \quad \% \quad \mathrm{H}_{2} \mathrm{O}_{2}$ (volume/volume) in methanol for 30 minutes at room temperature. Samples were then incubated overnight with rabbit monoclonal antibody to human P53 antibody (code no.: RMPD 016, ready-to-use 1ry antibody, DBS, CA, USA) which reacts with both the wild and the mutant types of human P53 protein, Bax epitope specific rabbit antibody (E3381, Spring Bioscience, CA, USA) and mouse monoclonal antibody to human Bcl-2 oncoprotein (code no.: PDM 016, ready-to-use 1ry antibody, DBS, CA, USA) at $4^{\circ} \mathrm{C}$. Sections were then immersed in a biotinylated secondary antibody diluted at 1:100 for 30 minutes and in avidin biotinylated peroxidase complex for 60 minutes (code no.: \# Kp-50L, DBS, CA 94566, USA). Slides were then treated with $100 \mu \mathrm{I}$ of freshly prepared DAB (3' 3' diaminobenzidine) solution for 10 min. Finally, slides were rinsed in running water, dehydrated in graded methanol, cleared in three changes of xylene and mounted in DPX then examined. Negative control sections were obtained by omitting the specific primary antibody from the staining process.

The level of expression was evaluated quantitatively according to scoring system made by Liang et al., (1999). Application of this system gives a score for both the degree of positivity (the number of positively stained keratinocytes/ 100 examined cells) and the degree of intensity of staining (Table, 1).

Table (1): Scoring system for quantifying the level of P53, Bax or Bcl-2 expression in epidermal keratinocytes (Liang et al., 1999).

\begin{tabular}{|c|c|c|l|}
\hline Score & Positivity & Score & \multicolumn{1}{c|}{ Intensity } \\
\hline 0 & $<1.0 \%$ & 0 & No staining (negative) \\
\hline 1 & $1-10 \%$ & 1 & Faint brown (mild-weak) \\
\hline 2 & $10-50 \%$ & 2 & Brown (moderate) \\
\hline 3 & $>50 \%$ & 3 & Deep brown (strong) \\
\hline
\end{tabular}

\section{Statistical analysis}

Statistical analysis of data was performed by using SPSS version 15.0 (SPSS Inc., Chicago, IL, USA) for windows. Results were expressed as mean values (M) and standard deviation $( \pm \mathrm{SD})$. Unpaired two-tailed Students't-test was performed to compare results. $\mathrm{P}$ Values of less than $<0.05$ was considered statistically significant. 


\section{Results}

The age of the road paving workers ranged from 30-55 years with a mean of 42 years and the exposure period to asphalt fumes ranged from $9-25$ years with a mean of 11.5 years.

General examination revealed that all participants were free of any medical diseases except ten complaining of hypertension. By local examination, many dermatologic toxic symptoms and signs were observed in 71 asphalt fumes exposed workers out of 122 presented $(58.19 \%)$ as erythema (8 cases), itching (19 cases), excoriations (13 cases), chronic dermatitis (16 cases), chemical keratosis (9 cases) and keratoacanthoma (K.A) (6 cases). For the last three disorders; the diagnosis was clinically and confirmed histopatholgically.

Nine out of $122(7.38 \%)$ workers examined were found to have skin lesions in the form of three skin ulcers, two hyperpigmented lesions and four fungating masses. They gave history of working in asphalt paving for more than 15 years before noting skin lesions. They were exposed to asphalt fumes on a nearly daily basis. Lesions were limited to lower lip (Fig.1), ear pinna (Fig.2), back of scalp, knee and the nostrils entrance. Clinical as well as histopathological examination revealed squamous cell carcinoma (SCC).

Histopathological examination of squamous cell carcinoma lesions revealed seven moderately differentiated SCC cases and two poorly differentiated SCC cases. Squamous cell carcinoma was characterized by typical keratinocytes presented in groups and nests of malignant squamous cells breaking through the basal membrane into the dermis.The keratinocytes lie in complete disorder. Cellular atypia, including pleomorphism, hyperchromatic nuclei, and mitoses are prominent. The moderately differentiated SCC showed an increased number of atypical keratinocytes and fewer horn-pearls, while the poorly differentiated SCC exhibited numerous atypical keratinocytes and rare horn pearl within atypical keratinocytes "with increasing malignancy; the atypical cells increased and the horn pearl become scanty" (Fig.3, 4).

The level of P53 expression in the epidermal keratinocytes of the control group ranged from $0.7-1.1$ with a mean of $0.84 \pm 0.16$. Immunoreactive

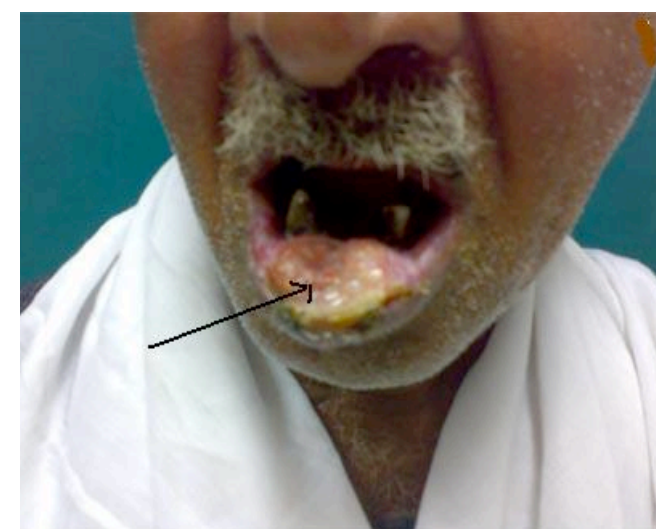

Fig.1: Photograph showing SCC of lower lip. keratinocytes exhibited nuclear staining and were limited to the basal cell layer of the epidermis indicating wild type (diffuse pattern) P53 expression (Fig.5). While the level of wild P53 expression in the epidermal keratinocyte of the asphalt fumes exposed uninvolved skin ranged from $0.62-1.9$ with a mean of (1.3 \pm 0.46$)$ (Fig.6). Mutant type P53 (compact pattern) was over-expressed in SCC cases with a level ranged from 16.64-63.48 with a mean of $49.60 \pm 32.7$ (Fig.7). A significant increase in P53 expression level in epidermal keratinocytes of asphalt fumes exposed normal uninvolved skin "non lesional" $(\mathrm{t}=2.51, \mathrm{P}=$ $0.04)$ and in SCC cases $(t=4.79, p=0.003)$ was observed when compared with the control group (Histogram 1).

Bax was overexpressed in all asphalt fumes exposed workers "either within PAHs exposed normal uninvolved skin or SCC lesions". The expression was cytoplasmic and its level in epidermal keratinocytes was 2.2-2.46 with a mean of $2.3 \pm 0.099,1.57-3.75$ with a mean of $2.81 \pm 0.59$ and $2.3-3.91$ with a mean of $(2.9 \pm 0.02)$ in the control group, asphalt fumes exposed normal uninvolved skin and SCC cases respectively (Fig. 8, 9, 10). A significant increase in Bax expression in epidermal keratinocytes of the asphalt fumes exposed workers and in SCC cases was observed when compared with the control group $(\mathrm{t}=$ 2.73, $\mathrm{P}=0.03 \& \mathrm{t}=2.98, \mathrm{P}=0.01$, respectively [Histogram 1]).

Bcl-2 expression of control group was confined to basal keratinocytes. They exhibited cytoplasmic staining with perinuclear enhancement (Fig. 11) with mean expression level of $2.69 \pm 1.7$. In asphalt fumes exposed normal uninvolved skin; Bcl- 2 was down regulated with a mean level of $1.3 \pm 1.2$ (Fig. 12).On other hand; none of the 9 tested SCC cases were positive for Bcl-2 (Fig. 13). A significant decrease in $\mathrm{Bcl}-2$ expression in epidermal keratinocytes of PAHs exposed subjects was noted ( $\mathrm{t}=$ 2.49, $\mathrm{P}=0.047$ ) (Histogram 1).

Number of positively immunostained cases, immunostaining intensity and the expression score for P53, Bax and Bcl-2 in both asphalt fumes exposed normal uninvolved skin and SCC cases in asphalt fumes exposed group are illustrated in tables 2,3 \& Fig. 14A \&14B.

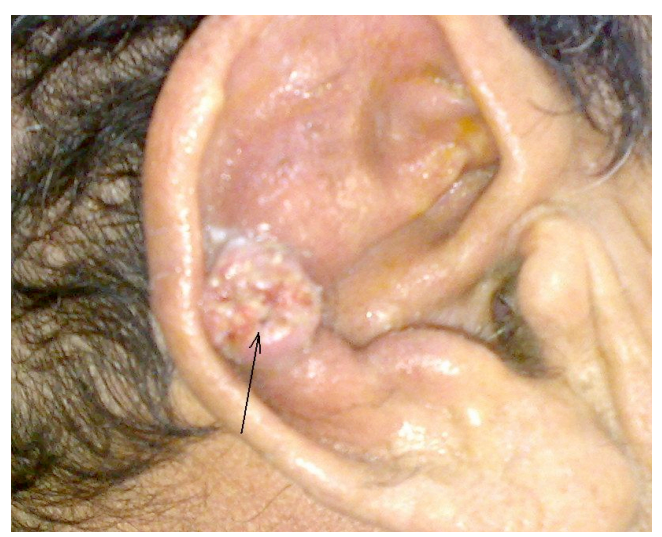

Fig.2: Photograph showing SCC of ear. 


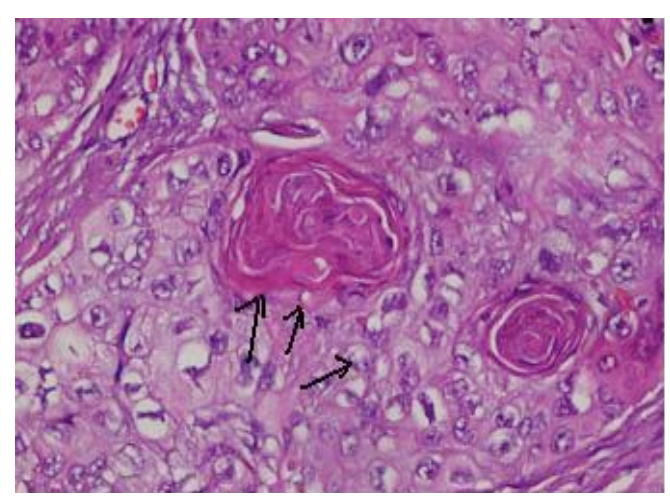

Fig.3: Photomicrograph showing moderately differentiated SCC, an increased of number atypical keratinocytes and fewer horn pearls (H\&E, x400).

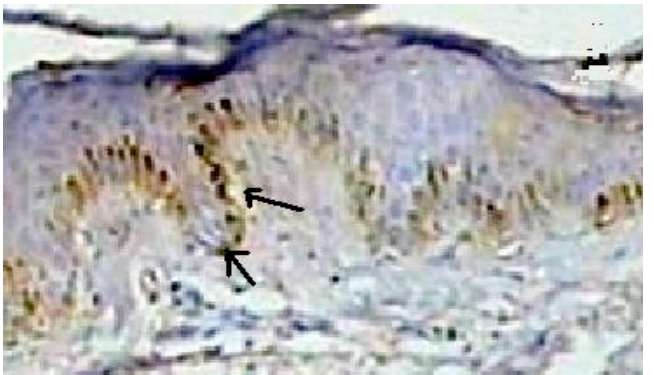

Fig.5: Photomicrograph showing positive nuclear $P 53$ expression in basal layer of epidermal keratinocytes of control group (Immunoperoxidase; $\mathbf{x 2 0 0}$ ).

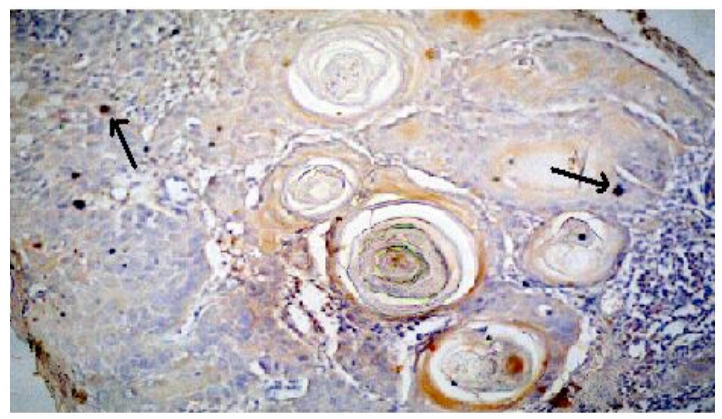

Fig.7: Photomicrograph showing positive nuclear P53 expression in SCC among asphalt fumes exposed group. (Immunoperoxidase; x200).

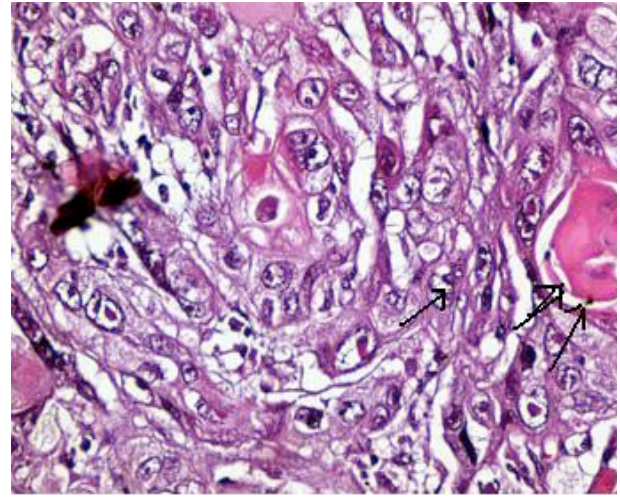

Fig.4: Photomicrograph showing poorly differentiated SCC with numerous atypical keratinocytes. Occasional horn pearl can be seen within atypical keratinocytes (H\&E, $\mathrm{x} 400)$.

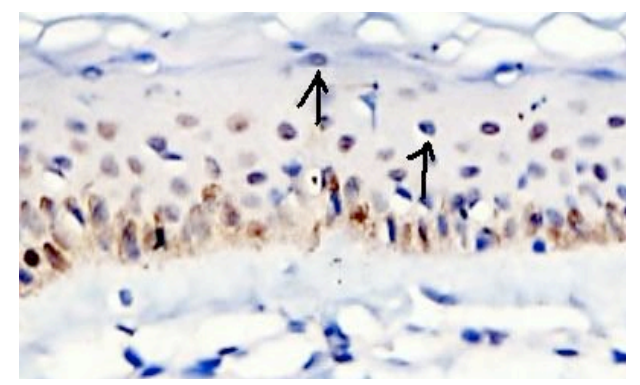

Fig.6: Photomicrograph showing increased nuclear P53 expression in epidermal keratinocytes of normal uninvolved skin of asphalt fumes exposed group. The expression extended from basal to granular cell layer (Immunoperoxidase; $\mathbf{x} 400$ ).

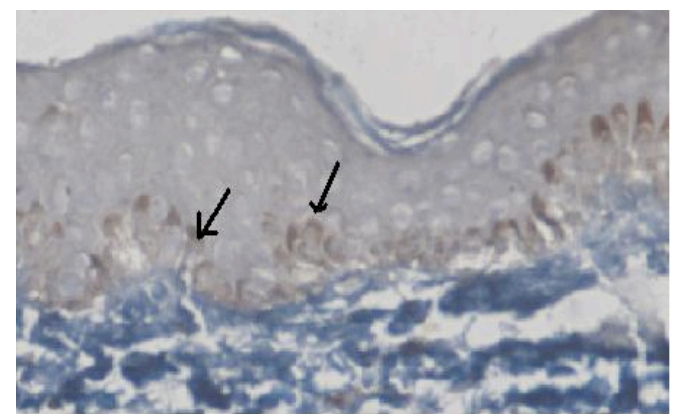

Fig.8: Photomicrograph showing cytoplasmic expression pattern of $\mathrm{Bax}$ in basal cell layer of the epidermal keratinocytes of control group (Immunoperoxidase $\times 400$ ). 


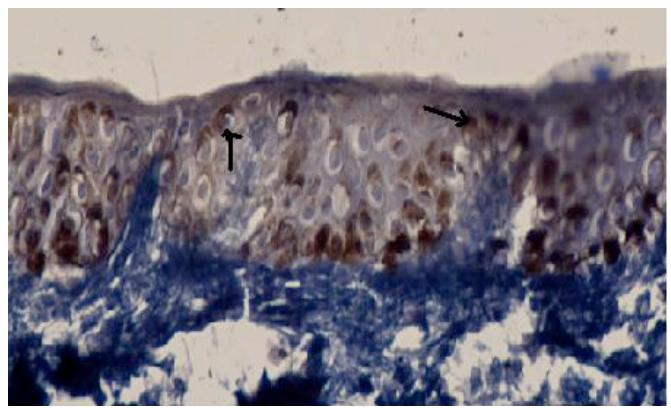

Fig.9: Photomicrograph showing Bax expression in all layers of epidermal keratinocytes of asphalt fumes exposed normal uninvolved group

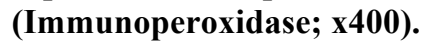

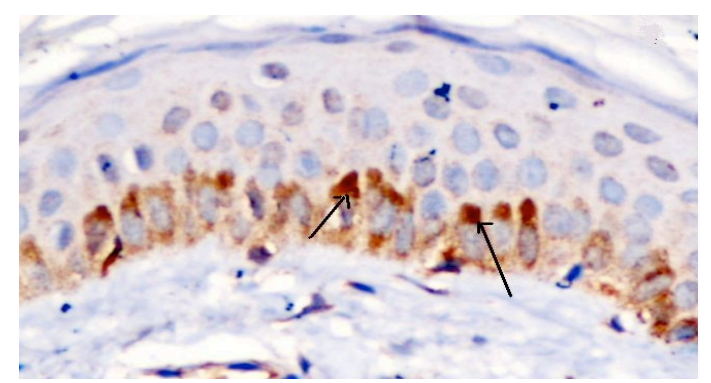

Fig.11: Photomicrograph showing cytoplasmic expression of Bcl-2 of basal cell layer in control skin (Immunoperoxidase; $\mathbf{x 4 0 0}$ ).

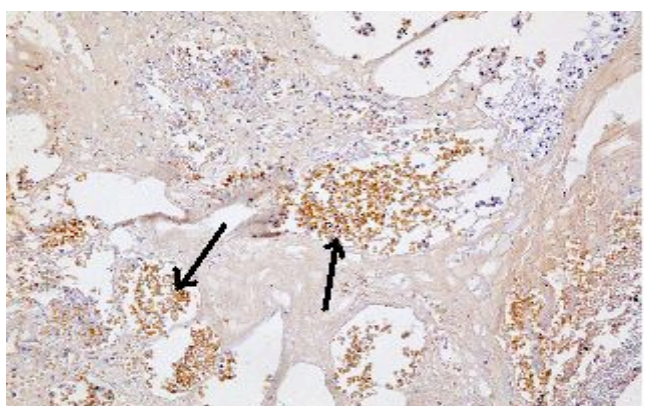

Fig.10: Photomicrograph showing higher Bax expression within SCC (Immunoperoxidase;

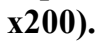

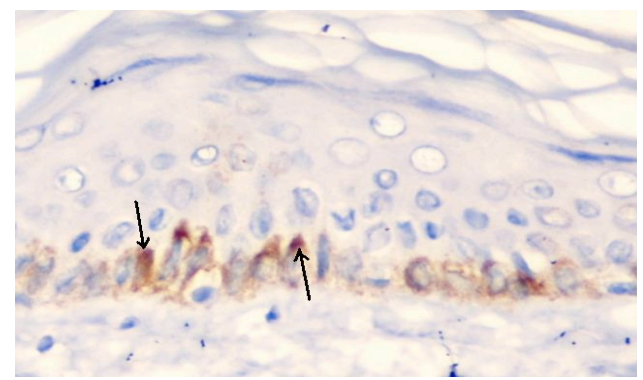

Fig.12: Photomicrograph showing low Bcl-2 expression in asphalt fumes exposed workers (Immunoperoxidase; $\mathbf{x 4 0 0 ) .}$

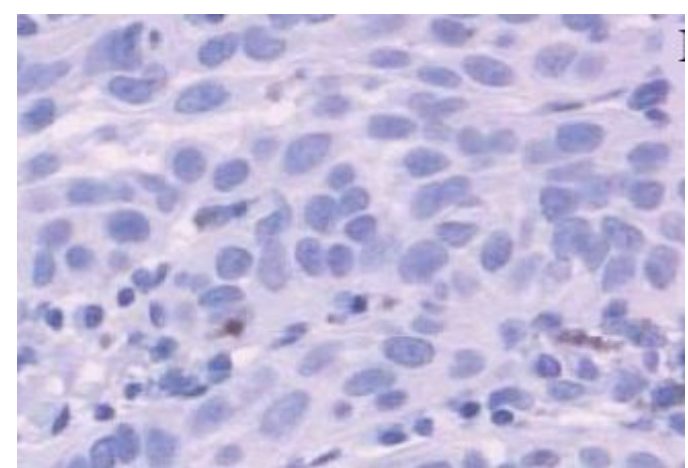

Fig. 13: Photomicrograph showing negative Bcl-2 expression in SCC (Immunoperoxidase; $x 400$ ). 


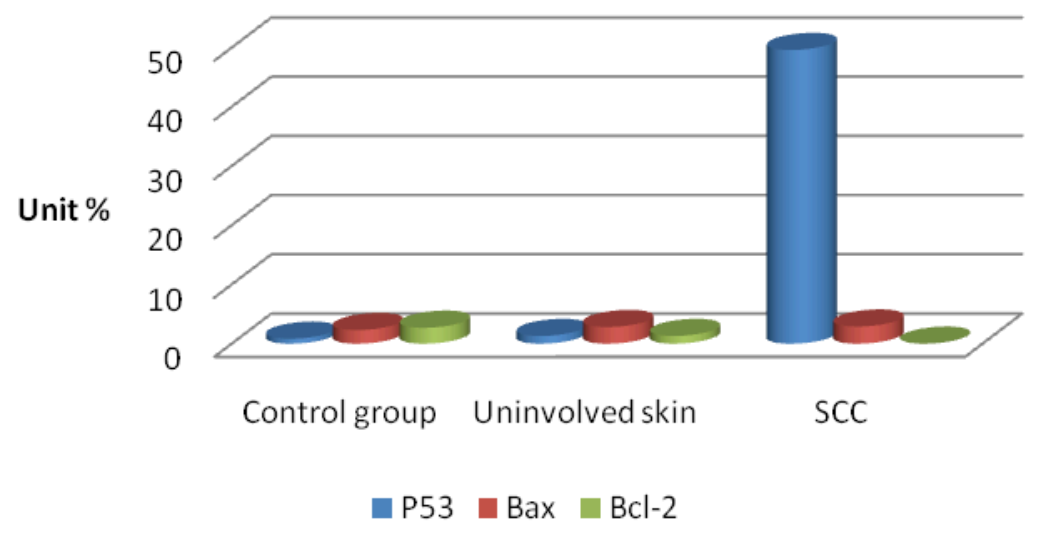

Histogram 1: The mean levels of P53, Bax and Bcl-2 among control and asphalt exposed groups (Control group= 30, exposed group $=122$ uninvolved skin $=113$, SCC cases $=9\})$.

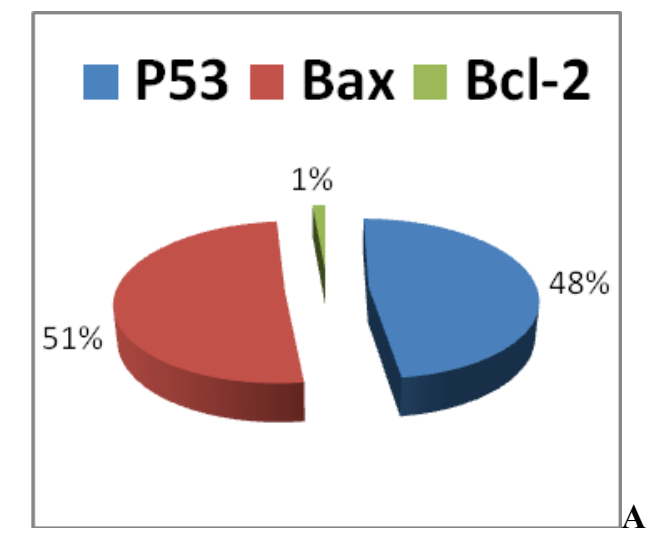

P53: 48\% Bax: 51\% Bcl-2: 1\%

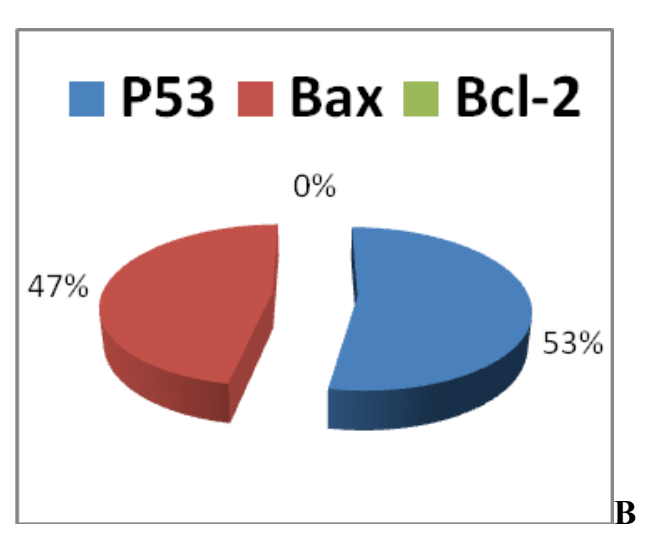

P53: 47\% Bax:53\% Bcl-2: 0\%

Figure 14: Pie chart shows immunostaining intensity of P53, Bax and Bcl-2 in uninvolved skin (A) and SCC (B) cases of asphalt-exposed group.

Table (2): Immunostaining intensity of P53, Bax and Bcl-2 in uninvolved skin and SCC cases of PAHs exposed group.

\begin{tabular}{|c|c|c|c|c|c|}
\hline \multicolumn{2}{|c|}{ Marker } & $\begin{array}{l}\text { No. of positive } \\
\text { cases }\end{array}$ & $\begin{array}{l}\text { No. of cases with } \\
\text { mild (weak) } \\
\text { staining intensity }\end{array}$ & $\begin{array}{c}\text { No. of cases with } \\
\text { moderate staining } \\
\text { intensity }\end{array}$ & $\begin{array}{c}\text { No. of cases with } \\
\text { strong staining } \\
\text { intensity }\end{array}$ \\
\hline \multirow{3}{*}{$\begin{array}{l}\text { PAHS exposed } \\
\text { uninvolved skin } \\
(n=113)\end{array}$} & P53 & 101 & 7 & 88 & 6 \\
\hline & $\operatorname{Bax}$ & 107 & 6 & 38 & 63 \\
\hline & Bcl-2 & 3 & 3 & 0 & 0 \\
\hline \multirow{3}{*}{$\begin{array}{l}\text { SCC cases } \\
(n=9)\end{array}$} & P53 & 9 & 0 & 7 & 2 \\
\hline & Bax & 8 & 1 & 6 & 1 \\
\hline & Bcl-2 & 0 & 0 & 0 & 0 \\
\hline
\end{tabular}

Table (3): Apoptotic markers expression score in uninvolved skin and SCC cases of PAHs exposed group

\begin{tabular}{|c|c|c|c|c|c|c|}
\hline \multicolumn{2}{|c|}{$\begin{array}{ll}\text { Markers } & \text { Score }\end{array}$} & $\begin{array}{c}\text { No. of positive } \\
\text { samples }\end{array}$ & $\begin{array}{l}<1.0 \% \\
\text { (score } 0)\end{array}$ & $\begin{array}{l}1-10 \% \\
\text { (score1) }\end{array}$ & $\begin{array}{l}10-50 \% \\
(\text { score } 2)\end{array}$ & $\begin{array}{l}>50 \% \\
(\text { score } 3)\end{array}$ \\
\hline \multirow{3}{*}{$\begin{array}{l}\text { PAHS exposed } \\
\text { uninvolved skin } \\
(n=113)\end{array}$} & P53 & 101 & 12 & 15 & 80 & 6 \\
\hline & Bax & 107 & 6 & 6 & 23 & 78 \\
\hline & Bcl-2 & 3 & 110 & 3 & 0 & 0 \\
\hline \multirow{3}{*}{$\begin{array}{l}\text { SCC cases } \\
(n=9)\end{array}$} & P53 & 9 & 0 & 1 & 4 & 4 \\
\hline & Bax & 8 & 1 & 0 & 2 & 6 \\
\hline & Bcl-2 & 0 & 9 & 0 & 0 & 0 \\
\hline
\end{tabular}




\section{Discussion}

Occupational exposure to hot asphalt may increase the risk of cancer (lung, stomach, bladder, leukemia and non-melanoma skin cancer) among asphalt workers (Mcclean et al., 2007). Changed expression of apoptosis related molecules could be detected during the process of malignant transformation and in malignant cells (Teo et al., 2007). As dermatotoxic and carcinogenic potentials of asphalt fumes are not fully clarified and mechanisms involved in PAHs-induced apoptosis are less characterized; so this work aimed to study chronic toxic effects of PAHs fumes on skin and to search for cellular pathways of apoptosis underlying malignant transformation through studying P53, Bax and $\mathrm{Bcl}-2$ apoptotic protein expression in skin of a population of road paving workers to assess the toxic role of asphalt fumes on apoptosis using immunohistochemical techniques.

The observed increased toxic skin symptoms in asphalt fumes exposed workers agree with what reported by (ATSDR, 1995; Wang et al., 2007; Bull, 2008). This may be explained on the basis that asphalt fumes exposure alters cutaneous barrier integrity and induce skin disease as the Egyptian workers don't follow safety protective measures. Results also proved an association between cancer risk and exposure to asphalt fumes where 9 chemical keratosis cases (with pre-cancerous potential) and 9 SCC cases were diagnosed which in line with (Partanen and Boffetta, 1994; Voelter et al., 2007).

Apoptosis which is equated to programmed cell death is an evolutionary conserved cell death process that plays a major role during normal development, homeostasis and elimination of potentially dangerous cells. The ordered execution of this internal death program leads to typical morphological and biochemical changes (Sinha Hikim and Swerdloff, 1999). Dysregulation of the apoptotic process may result in a wide range of pathological conditions as cancers, autoimmune diseases, and viral infections (Cecilia et al., 2007).

In this study; asphalt fumes were found to induce activation of apoptosis as defense mechanism from the body, where both wild type P53 (tumour suppressor gene) and Bax protein (pro-apoptotic protein) were over-expressed and Bcl-2 (the major anti-apoptotic protein) was downregulated which is in the same line with (Ponten and Lundeberg, 2003; Solhaug et al., 2004; Moll et al., 2005). The activated apoptosis act as a defense mechanism to prevent PAHs toxic effect as it helps exposed workers to get rid of harmed cells and to prevent progression to carcinoma. Increased P53 expression level suggests that PAHs induced apoptosis is triggered by the induced DNA damage in P53-dependent pathway. P53 in its natural form (wild-type) upregulates P21 causing cell cycle arrest to allow repair of damaged DNA (Barakat and Abd-Elghany, 2007). Road paving asphalt fume was found by De Meo et al., (1996) to be mutagenic and induced DNA damage and adduct formation. DNA damage initiates a number of cell signaling pathways that may result in cell cycle delays, senescence or cell death. The key point of these changes is the tumour suppressor P53 (Niida and Nakanishi, 2006). Following DNA damage P53 is phosphorylated thereafter translocated to the nucleus where it may result in cell cycle arrest, allowing time for DNA repair or triggering apoptosis (Efeyan and Serrano, 2007). If damage is extensive, P53 induces apoptotic cell death by downregulating $\mathrm{Bcl}-2$ and upregulating $\mathrm{Bax}$ expression (Barakat and Abd-Elghany, 2007).

Comparatively, we were able to further substantiate this hypothesis as we found an increased level of Bax which is involved in triggering the apoptotic process as Bax is known to be a downstream target of P53 and is often induced and/or translocated to mitochondria as a part of the apoptotic process (Landvika et al., 2010). The enhanced apoptosis was also confirmed from the observed lowered expression level of Bcl-2. Bcl-2 is a proto-oncogene that encodes the largest known anti- apoptotic protein. Bcl-2 regulates apoptosis through the formation of homodimer proteins with the other proteins belonging to the Bcl-2 group, especially the pro-apoptotic protein Bax (Verhaegh et al., 1995).

Asphalt fumes, induced apoptosis may also have a role in cancer initiation and promotion. Results showed significantly increased expression levels of mutant P53 in SCC cases. The observed higher level of mutant P53 accompanied with high Bax expression may explain the aggressive behavior of SCC as the mutant type P53 protein was unable either to induce apoptosis or to suppress SCC development and progression (Chan et al., 1995). Mutation in P53 gene leads to the loss of its repair function and thus apoptosis resistance of the DNA-damaged cell and hence cancer development (Peter et al., 2005). Hussain and Harris (2007) found that mutations in P53 gene are the most frequently observed genetic alteration in cancer. P53 mutation may occur due to chromosomal instability, reactive nitrogen and oxygen species and formation of reactive metabolites which induce mutations (Vom et al., 2009).

The lack of Bcl-2 expression in SCC confirm the hypothesis that most of tumor cells originate from the suprabasal keratinocytes which normally have negative Bcl-2 expression ( $\mathrm{Lu}$ et al., 1993). The negative Bcl-2 expression in SCC was unexpected as Bcl-2 is known to protect tumor cells from apoptosis (Xie et al., 1999). This may be possibly compensated by over expression of other anti-apoptotic proteins (not included in the study). So, it is suggested that disturbed apoptosis and SCC formation in PAHs exposed workers is not $\mathrm{Bcl}-2$ dependent. Although the relatively high expression level of Bax; it appears to be unable to suppress the tumor progression. This may be due to expression of functionally inactive Bax (Kurabayashi et al., 2001). Another explanation to tumor formation was reported by Holme and Solhaug (2005) where they stated that although apoptosis of cells exposed to PAHs is considered to function anti-carcinogenic since cells with extensive DNA damage will be removed, it is possible on other hand that removal of these cells may 
give survival and proliferating signals to surrounding cells with less DNA-damage, increasing their probability of having mutations and give promotion signals to cell proliferation and hence cancer formation.

\section{Conclusion and Recommendation}

- This work makes it clear that asphalt workers who exposed continuously to asphalt fumes are at great risk to develop serious skin disorders including cancers so, it is recommended that they follow protective safety measures including wearing protective gloves, boots, aprons, and gauntlets as needed to prevent prolonged or repeated skin exposure. Goggles and face shields should be used in areas where splashing may occur.

- Workers who developed skin disorders must seek professional medical help and are advised to move to another job away from continuous asphalt exposure.

- Asphalt fumes exposure may increase the risk for developing dermatotoxic and/or cancer through disturbing apoptosis. Although PAHs exposure can disturb P53, Bax and Bcl-2 apoptotic proteins, more extensive researches on other factors involved in controlling apoptosis as Bcl-xl, Caspase family and Fas are to be undertaken.

Abbreviation: STDs: Sexually Transmitted Disease

\section{References}

Agency for Toxic Substances and Disease Registry (ATSDR) (1995): Toxicological Profile for Polycyclic Aromatic Hydrocarbons (PAH). US Department of Health and Human Services. Atlanta, US. Accessed 12.09.2010.

Alguire PC and Mathes BM (1998): Skin biopsy techniques for the internist. $\mathrm{J}$ Gen Intern Med.13(1): 40-54.

Barakat M and Abd-Elghany M (2007): Expression of Apoptosis and cell cycle regulatory proteins in cutaneous Squamous Cell Carcinoma. PALD. $18(3): 31-41$.

Boffetta P, Jourenkova N and Gustavsson P (1997): Cancer risk from occupational and environmental exposure to polycyclic aromatic hydrocarbons. Cancer Causes Control. 8: 444-72.

Boffetta P, Burstyn I, PartanenTH et al., (2003): Cancer mortality Among European asphalt workers: an international epidemiological study. II. Exposure to bitumen fume and other agents. Am J Ind Med. 43: 28-39.

Bull SC (2008): Polycyclic aromatic hydrocarbons (Benzo[a]pyrene): Toxicological overview. 2008 Version.

Cecilia B, Inger R and Karin Ö (2007): Hsp70 protects against UVB induced apoptosis by preventing release of cathepsins and cytochrome $\mathrm{c}$ in human melanocytes. Carcinogenesis. 28(3): 537-544.

Ceinwen AS (2011): Review of mechanistic studies relevant to the potential carcinogenicity of asphalts. Regulatory Toxicology and Pharmacology. 59: 270-284.

Chan S, Jong O and Kim I (1995): Detection of Bcl-2 family and Bax in head and neck cancers. J. Korean Cancer Association. 27 (4):570- 77.

Chin BY, Choi ME, Burdick MD et al., (1998): Induction of apoptosis by particulate matter: role of TNF-alpha and MAPK. Am. J. Physiol. 275: L942-L949.

De Meo M, Genevois C, Brandt H et al., (1996): In vitro studies of the genotoxic effects of bitumen and coal-tar fume condensates: comparison of data obtained by mutagenicity testing and DNA adduct analysis by $32 \mathrm{P}$ postlabelling. Chem. Biol. Interact. 101: 7388.

Efeyan AM and Serrano M (2007): p53: guardian of the genome and policeman of the oncogenes. Cell Cycle. 6: 1006-1010.

Erb P, Ji J, Wernil M et al., (2005): Role of apoptosis in basal cell and squamous cell carcinoma formation. Immunol. Lett. 100: 68-72.

Gosset P, Garcon G, Casset A et al (2003): Benzo(a)pyrene-coated onto $\mathrm{Fe}(2) \mathrm{O}(3)$ particles-induced apoptotic events in the lungs of Sprague-Dawley rats. Toxicol. Lett. 143: 223--232.

Harrison RJ (2004): Polycyclic aromatic hydrocarbons, In: Current Occupational and Environmental Medicine (La Dou J, ed.). New York: McGraw-Hill. 492-493.

Holme JA and Solhaug A (2005): PAH-induced apoptosis. Abstracts / Toxicology Letters. 158S: S21-S258.

Hussain SP and Harris CC (2007): Inflammation and cancer: an ancient link with novel potentials. Int. J. Cancer, 121: 2373-2380.

King RW, Puzinauskas VP and Holdsworth CE (1984): Asphalt composition and health effects: A critical review, American Petroleum Institute Technical Publication, Washington, DC. p: 111.

Kurabayashi A, Furihata M, Matsumoto $M$ et al., (2001): Expression of Bax and apoptosisrelated proteins in human esophageal squamous cell carcinoma including dysplasia. 14 (8):741-7.

Landvika NE, Arlt VM, Nagy E et al., (2010): 3Nitrobenzanthrone and 3-aminobenzanthrone induce DNA damage and cell signalling in Hepalc1c7 cells. Mutation Research/Fundamental and Molecular Mechanisms of Mutagenesis. 684 (1-2): 1123.

Lei W, Yu R, Mandlekar S et al., (1998): Induction of apoptosis and activation of interleukin 1betaconverting enzyme/Ced-3 protease (caspase3) and c-Jun NH2-terminal kinase 1 by benzo(a)pyrene. Cancer Res. 58: 2102-2106. 
Liang SB, Ohtsuki Y, Furihata M et al., (1999): Sunexposure- and aging-dependent P53 protein accumulation results in growth advantage for tumor cells in carcinogenesis of nonmelanocytic skin cancer. Virchows Arch. 434:193-199.

Lu QL, Poulsom R, Wong L et al., (1993): Bcl-2 expression in adult and embryonic nonhaematopoietic tissues. J Pathol; 169: 431-7.

McClean MD, Wiencke JK, Kelsey KT et al., (2007): DNA Adducts among Asphalt Paving Workers. Ann. Occup. Hyg. Vol. 51 (1): 2734.

Michael F (1999): Asphalt. Chemical and Engineering. 77 (47): 81.

Moll UM, Wolff S, Speidel D et al., (2005): Transcription-independent pro-apoptotic functions of p53. Curr. Opin. Cell Biol.17: 631-636.

Monika RH, Boleslaw M, Anne S et al., (2011): Bitumen workers handling mastic versus rolled asphalt in a tunnel: assessment of exposure and biomarkers of irritation and genotoxicity. Arch Toxicol. 85 (Suppl 1):S81S87.

Niida $\mathrm{H}$ and Nakanishi M (2006): DNA damage checkpoints in mammals. Mutagenesis. 21: 39 .

Okona-Mensah KB, Battershill J, Boobis A et al., (2005): An approach to investigating the importance of high potency polycyclic aromatic hydrocarbons (PAHs) in the induction of lung cancer by air pollution. Food and Chemical Toxicology. 43: 11031116.

Parker CM, Schreiner CA, Hallmark N et al., (2011): Evaluation of reproductive/developmental and repeated dose (subchronic) toxicity and cytogenetic effects in rats of a roofing asphalt fume condensate by nose-only inhalation. Regulatory Toxicology and Pharmacology. 59 (3): 445-453.

Partanen T and Boffetta P (1994): Cancer risk in asphalt workers and roofers: review and metaanalysis of epidemiologic studies. Am. J. Ind. Med. 26: 721-740.

Petrusz A and Ordronneau C (1983): Immunocytochemistry in Practical applications in pathology and biology by Polak \&Van noordeen "eds." Bristol wrightPSG: 212.

Peter E, Jingmin Ji, Marion W et al., (2005): Role of apoptosis in basal cell and squamous cell carcinoma formation. Immunology Letters. 100 (1): 68-72.

Ponten F and Lundeberg J (2003): Principles of tumor biology and pathogenesis of basal cell carcinoma and squamous cell carcinoma. In: Dermatology (edited by JL Bolognia, JL Jorizzo and RP Rapini), $1^{\text {st }}$ edn, volume 2,
Mosby (an imprint of Elsevier Science), Spain, p. 1663.

Salas VM and Burchiel SW (1998): Apoptosis in Daudi human $B$ cells in response to benzo[a]pyrene and benzo[a]pyrene-7, 8dihydrodiol. Toxicol. Appl. Pharmacol. 151: 367-376.

Sinha Hikim AP and Swerdloff RS (1999): Hormonal and genetic control of germ cell apoptosis in the testis. Reviews of Reproduction. 4:38-47.

Sivak A, Niemeier R, Lynch D et al., (1997): Skin carcinogenicity of condensed asphalt roofing fumes and their fractions following dermal application to mice, Cancer Lett. 117: 113123.

Solhaug A, Magne R, Marit L et al., (2004): Polycyclic aromatic hydrocarbons induce both apoptotic and anti-apoptotic signals in Hepa1c1c7 cells. Carcinogenesis,; 25 (5): 809-819.

Teo M B, Tanja B, Ita H et al., (2007): Apoptosis and immune response are responsible for the sitespecific incidence of non-melanoma skin cancer. Medical Hypotheses. 68(4):853-855.

Timothy D (2009): Apoptosis. www.about.com: Skin cancers.

Verhaege ME, Sanders CJ, Arends JW et al., (1995): Expression of the apoptosis-suppressing protein Bcl-2 in non-melanoma skin cancer. Br J Dermatol. 132: 740-4.

Voelter MS, Scheriau R, Zwahr G et al., (2007): Skin tumors among employees of a tar refinery: the current data and their implications. International Archives of Occupational and Environmental Health. 80 (6): 485-495.

vom BJ, Krais A, Whibley C et al., (2009): The carcinogenic air pollutant 3-nitrobenzanthrone induces GC to TA transversion mutations in human p53 sequences. Mutagenesis. 24: 1723.

Wang S, Sheng Y, Feng M et al., (2007): Lightinduced cytotoxicity of 16 polycyclic aromatic hydrocarbons on the US EPA priority pollutant list in human skin $\mathrm{HaCaT}$ keratinocytes: relationship between phototoxicity and excited state properties. Environ Toxicol. 22(3):318-27.

Xie X, Clausen OP, De Angelis P et al., (1999): The prognostic value of spontaneous apoptosis, Bax, Bcl-2 and P53 in oral squamous cell carcinoma of the tongue. Cancer. 86 (6): 913920.

Yvonne CM (2007): Polycyclic aromatic hydrocarbon induced effects on gene expression in relation to carcinogenic potency. M.D. essay (C) copyright Y.C.M Staal, Maastricht. ISBN 978-90-5278-612-4 Universitaire Pers Maastricht.

Zhaoa HW, Yin XJ, Frazer D et al., (2004): Effects of paving asphalt fume exposure on genotoxic and mutagenic activities in the rat lung. Mutation Research. 557: 137-149. 
الملخص العربي

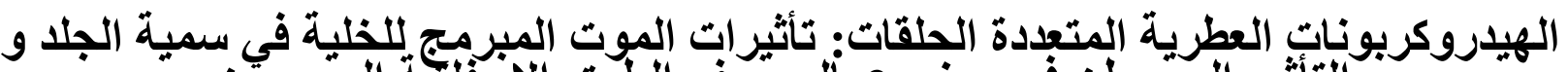

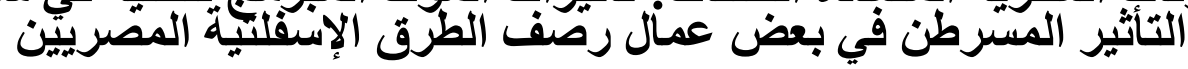

\section{غادة عطية اسحق 1 و موريد ملاك حنا1 و منال إسماعيل احمد2 و غادة علي ناصف3 3}

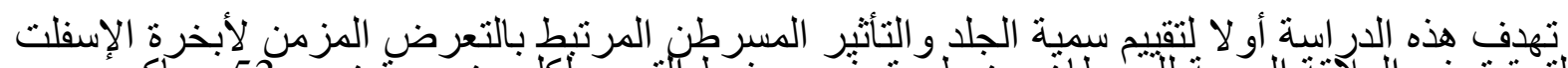

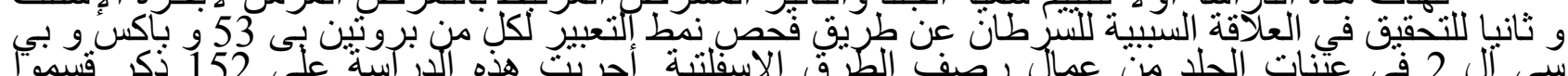

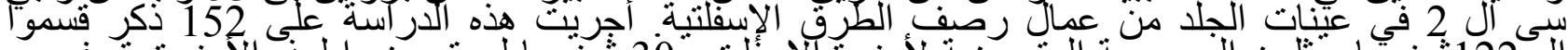

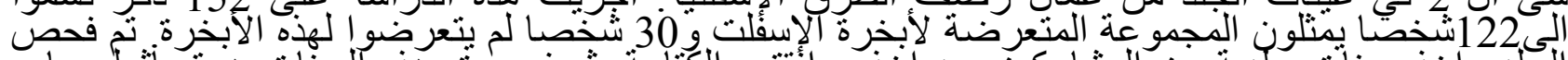

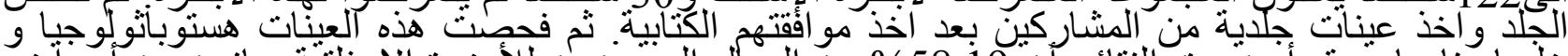

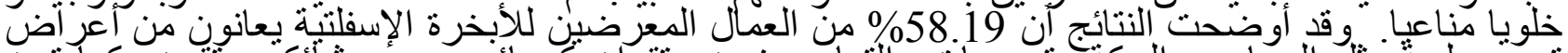

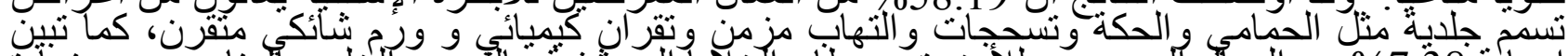

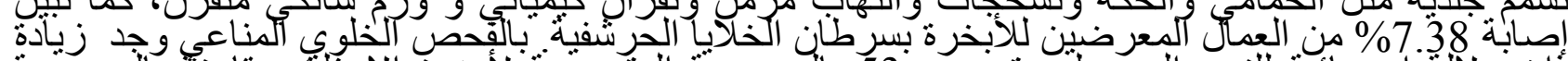

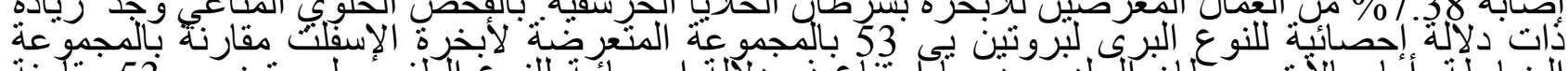

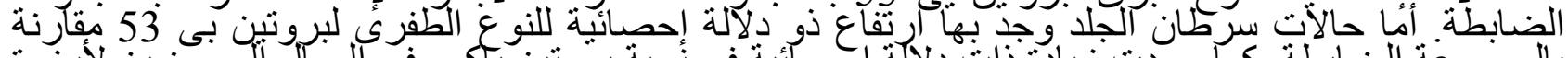

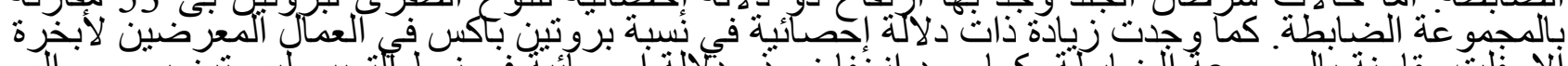

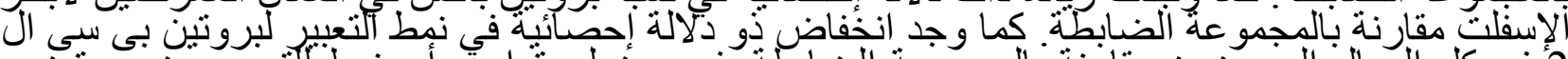

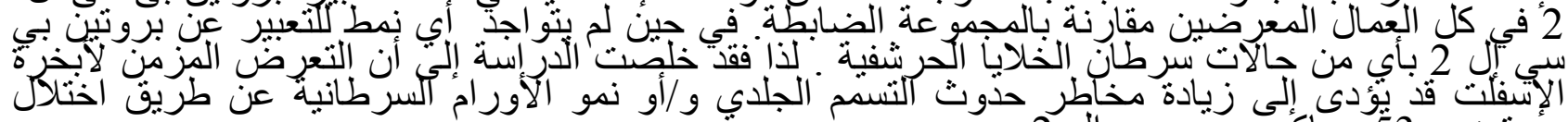

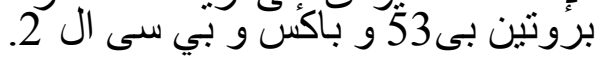

\footnotetext{
1 قسم الطب الثر عي و السموم الإكلينيكية

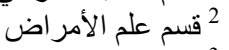

3 قسم الجلدية و التناسلية و أمر اض الذكورة

كلية الطب جامعة المنيا 